\title{
Activation of the iNOS/NO/cGMP pathway by Revactin $®$ in human corporal smooth muscle cells
}

\author{
Monica G. Ferrini ${ }^{1,2}$, Andrea Abraham ${ }^{1}$, Leslie Graciano ${ }^{1}$, Sabine Nguyen ${ }^{1}$, Jesse N. Mills ${ }^{3}$, Jacob Rajfer ${ }^{3}$ \\ ${ }^{1}$ Department of Health and Life Sciences, Charles R. Drew University of Medicine and Science, Los Angeles, California, USA; ${ }^{2}$ Department of \\ Medicine, David Geffen School of Medicine at UCLA, Los Angeles, CA, USA; ${ }^{3}$ Department of Urology, David Geffen School of Medicine at \\ UCLA, Los Angeles, CA, USA \\ Contributions: (I) Conception and design: MG Ferrini, J Rajfer; (II) Administrative support: MG Ferrini, A Abraham; (III) Provision of study materials \\ or patients: JN Mills, J Rajfer; (IV) Collection and assembly of data: MG Ferrini, A Abraham, L Graciano, S Nguyen, JN Mills; (V) Data analysis and \\ interpretation: MG Ferrini, J Rajfer; (VI) Manuscript writing: All authors; (VII) Final approval of manuscript: All authors. \\ Correspondence to: Monica G. Ferrini, MS, PhD. Department of Health and Life Sciences, Charles R. Drew University of Medicine \& Science, 1731 \\ East 120th Street, Los Angeles, California 90059, USA. Email: monicaferrini@cdrewu.edu.
}

Background: The combination of the nutraceuticals, Paullinia cupana, ginger rhizome, muira puama, and the amino acid L-citrulline (COMP-4) has been shown to stimulate the production of inducible nitric oxide synthase (iNOS), nitric oxide (NO), and cGMP in rat corpora cavernosa smooth muscle cells (CSMC). When administered to middle-aged rats, long-term treatment with COMP-4 resulted in both an increase in the number of CSMC and an improvement in erectile function. We, therefore, aimed to determine whether

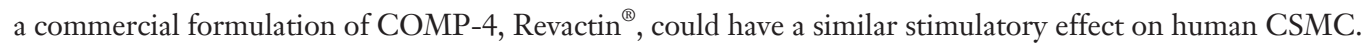
Methods: Primary human CSMC cultures (HCSMC) were grown and incubated with Revactin ${ }^{\circledR}$ for up to 24 hours. cGMP generation and nitrite formation were determined by ELISA and Griess reaction, respectively. IBMX $(1 \mathrm{mM})$, sildenafil $(0.4 \mathrm{mM})$, and L-NIL $(4 \mu \mathrm{M})$ were utilized as modulators of the NOcGMP pathway. iNOS, endothelial NOS (eNOS), and neuronal NOS (nNOS) expressions were determined by Western blot.

Results: Revactin ${ }^{\circledR}$ up-regulated both nitrite formation and cGMP expression, achieving the highest expression at 24 hours in the HCSMC. These effects were completely blocked by L-NIL. Revactin ${ }^{\circledR}$ up- $^{-}$ regulated iNOS expression, but not that of eNOS or nNOS.

Conclusions: The results presented in this study confirmed that Revactin ${ }^{\circledR}$ activated the iNOS-NOcGMP pathway intracellularly in HCSMC. It still needs to be determined whether the upregulation of this pathway would be an effective approach for counteracting the fibrosis and apoptosis of the corporal smooth muscle cells associated with aging.

Keywords: Inducible nitric oxide synthase (iNOS); cGMP; nitric oxide (NO); cavernosal smooth muscle cells (CSMC); erectile function

Submitted Jan 05, 2021. Accepted for publication Apr 25, 2021.

doi: $10.21037 /$ tau-21-11

View this article at: https://dx.doi.org/10.21037/tau-21-11

\section{Introduction}

Erectile dysfunction (ED), defined as the inability to attain or sustain an erection during sexual intercourse, is estimated to affect approximately $52 \%$ of men aged 40 -70 years (1). The predominant cause of ED, regardless of age, appears to be cavernosal veno- occlusive dysfunction (CVOD) or venous leakage (2), which is primarily due to the progressive loss of the CSMC, leading to a relative increase in cavernosal fibrosis $(3,4)$. It is estimated that CVOD becomes clinically apparent when there is a loss of approximately $10-20 \%$ of the corporal smooth muscle cells 
$(\operatorname{HCSMC})(5,6)$.

The current treatments available for men with ED, while they may allow men to get an on-demand erection, are simply palliative and do not target the cause of the dysfunction.

The phosphodiesterase (PDE) type 5 inhibitors such as sildenafil, tadalafil, etc., are usually the first-line treatment for men with ED. However, they are only effective in producing a satisfactory erection in about $60-75 \%$ of men who initially try it (7-9); however, over time, the majority of these men who initially respond to these drugs will ultimately fail this treatment (10). This failure is definitely not due to tachyphylaxis of the drug $(11,12)$ but is presumed to be due to the progressive ongoing aging related apoptosis of the HCSMC (13). It has been suggested that when such aging-related apoptosis occurs, it appears to be associated with an increase in intracellular oxidative stress within the corporal tissue (14). In an attempt to counteract the oxidative stress causing this apoptotic process, the CSMC themselves begin to produce nitric oxide (NO) via the normally inactive inducible nitric oxide synthase (iNOS) enzyme (15-17).

The NO emanating from this endogenous process within the CSMC has been shown to neutralize oxidative stress and reduce the ongoing apoptotic process (15).

It was recently reported in the rat that the oral administration of a nutraceutical composition (COMP-4) consisted of muira puama, ginger rhizome, and Paullinia cupana together with the amino acid, L-citrulline, reversed the corporal apoptosis and fibrosis as well as corrected the CVOD observed in the aged rat (18). The proposed mechanism of action of COMP-4 was activation of the relatively dormant iNOS-NO-cGMP pathway within the CSMC (19). This increase in NO and cGMP via iNOS was postulated to promote the reduction in apoptosis and fibrosis as well as the improvement in the erectile function observed in the aging rat penis (18).

Commercially, COMP-4 is marketed as Revactin ${ }^{\circledR}$, and while slightly different in its composition from COMP-4, it was employed in a 3 -month pilot clinical trial that showed a significant early improvement in erectile function $(20,21)$. It was theorized at that time that the improvement in erectile function in these men could possibly be due to the putative elevation in levels of cGMP produced via the activation of the iNOS-cGMP pathway.

In order to answer the question of whether the improvement in erectile function observed in men taking Revactin $\AA$ could be ascribed to the activation of the endogenous iNOS-cGMP pathway in the HCSMC, a study using a human primary CSM in vitro model was performed to evaluate the effect of Revactin ${ }^{\circledR}$ on cGMP and nitrite formation as well as its effect on the nitric oxide synthases (nNOS, eNOS, and iNOS).

We present the following article in accordance with the MDAR checklist (available at https://dx.doi.org/10.21037/ tau-21-11).

\section{Methods}

\section{Cell cultures}

Primary HCSMC were initiated from snippets of corporal tissue removed from male patients $(n=4)$ undergoing an invasive penile surgical procedure on the corpora cavernosa. The study was conducted in agreement with the Declaration of Helsinki (as revised in 2013), and it was approved as exempt by the UCLA IRB \#19-001074, and by the CDU IBC \#18-07-0034-01-03. The individual's consent for this study was waived.

The corpora cavernosa explants were attached to a T75$\mathrm{cm}^{2}$ flask incubated in Dulbecco's modified Eagle's medium (DMEM) supplemented with 20\% fetal calf serum and $1 \mathrm{X}$ antibiotic-antimycotic solution (Corning Technology, Corning NY Cat\# 30-004-CI) (19,24). The tissue explants were cultured at $37{ }^{\circ} \mathrm{C}$ in a $5 \% \mathrm{CO}_{2}$ incubator for a week, avoiding the tissue's dislodgment. The tissue was removed when the cells started migrating from the tissue. After trypsinization, cells were then transferred to a new $T 75-\mathrm{cm}^{2}$ flask at a ratio of $0.5 \times 10^{6}-1.0 \times 10^{6}$ cells per flask and grown in human smooth muscle growth medium (Cell Applications Inc; Cat\# 311-500, San Diego CA) until reaching confluency at $8.0 \times 10^{6}$ cells per flask. For the experiments, cells between the second and fifth passages were seeded in 6-wells plates at $0.3 \times 10^{6}$ cells until they reached confluency at $1.0 \times 10^{6}$ to start the treatments.

\section{Preparation of Revactin ${ }^{\circledR}$}

Revactin ${ }^{\circledR}$ was a gift of MD Concepts (New York, NY). The normal daily dose of Revactin ${ }^{\circledR}$ in human is $500 \mathrm{mg}$ each of muira puama, ginger rhizome, and Paullinia cupana, the latter containing $12.0 \%$ caffeine, as well as $1,600 \mathrm{mg}$ of L-citrulline. In order to determine which concentration of Revactin ${ }^{\circledR}$ would be safe for cell viability, and to correlate these experiments with the dosage of Revactin ${ }^{\circledR}$ used in the aforementioned clinical studies $(20,21)$, three different 
concentrations of Revactin ${ }^{\circledR}$, were prepared at $50 \%$ $(0.345 \mathrm{mg} / \mathrm{mL}), 100 \%(0.69 \mathrm{mg} / \mathrm{mL})$, and $200 \%$ $(1.38 \mathrm{mg} / \mathrm{mL})$. The concentrations used in the cell culture experiments correlate with the above-mentioned human dose of Revactin ${ }^{\circledR}(20,21)$. The contents within the Revactin ${ }^{\circledR}$ capsule were dissolved in $0.07 \%$ ethanol.

The phosphodiesterase inhibitor, 3-isobutyl-1methylxanthine (IBMX; cat\# 13347), the phosphodiesterase V inhibitor, Sildenafil (SIL; Cat\# 139755-83-2), and the iNOS specific inhibitor, N6-(1-iminoethyl)- $L$ lysine, dibydrochloride (L-NIL; cat\#: 80310) were obtained from Cayman Chemical Company (Ann Arbor, MI) and used at a concentration of $1 \mathrm{mM}$ for IBMX, $0.4 \mathrm{mM}$ for SIL, and $4 \mu M$ for L-NIL, respectively.

\section{Immunocytochemistry of alpha smooth muscle actin and desmin}

HCSMC were seeded at 40,000 cells per well in four-well Nunc ${ }^{\circledR}$ Lab-Tek $^{\circledR}$ chamber slides (Thermo Fisher, Waltham MA) until they reach confluency. Cells were fixed with $10 \%$ formalin for 20 minutes. After quenching for endogenous peroxidase activity with $3 \% \mathrm{H}_{2} \mathrm{O}_{2}$, cells were permeabilized with $0.3 \%$ Triton in PBS and then blocked with $10 \%$ normal horse serum or normal goat serum in $0.3 \%$ Triton-PBS. Cells were then incubated with: (I) a monoclonal antibody against alpha-smooth muscle actin at a dilution of 1:400 (Sigma Aldrich Cat\#: A5228, RRID: AB_262054, St Louis, MO, USA), and (II) a polyclonal antibody made in rabbit against desmin at 1:400 dilution (AbCAM Cat\#: ab32362 RRID:AB_731901, Cambridge, UK). After several washes with PBS, an incubation with 1:200 dilution of either horse anti-mouse (Cat\# BA-2000 RRID:AB_2313581) or goat anti-rabbit (Cat\# BA-1000, RRID:AB_2313606) biotinylated secondary antibodies from Vector Laboratories (Burlingham, CA, USA) was performed, followed by the ABC complex in 1:100 dilution (Vectastain Elite ABC System Cat\#: PK 6100, Vector Laboratories). As chromogen, 3-amino-9ethylcarbazole in buffer acetate and $0.06 \%$ of $\mathrm{H}_{2} \mathrm{O}_{2}$ (Sigma Aldrich; Cat\#: AEC 101) was used. Hematoxylin was used as a counterstaining. Slides were detached from the chambers, and a coverslip was mounted with aqua-mount mounting media (Vector Laboratories; Cat\#: H5501). The first antibody was omitted as negative control $(22,23)$.

\section{Determination of cGMP}

The HCSMC were seeded at $0.3 \times 10^{6}$ cells per well in a 6-well plate, and after reaching confluency, cells were incubated with vehicle or with different concentrations of Revactin $^{\circledR}$ for 24 hours. A time course at $0,3,6,12$, and 24 hours incubation with $100 \%$ of Revactin ${ }^{\circledR}$ and with $0.4 \mathrm{mM}$ sildenafil as a positive control was also performed.

The incubations with the treatments and inhibitors were stopped by removing the media and the addition of HCL $0.1 \mathrm{M}$ for 20 minutes. Cells were then homogenized and centrifuged at $1,000 \mathrm{~g}$ for 10 minutes. The supernatants were used for the determination of cGMP concentration by a colorimetric ELISA (Cayman Chemical Company, Cat\#: 581021, Ann Arbor, MI), following the manufacturer's instructions without acetylation. The results were expressed as $\mathrm{pmol} / \mathrm{mg}$ protein (24).

\section{Determination of nitrite formation}

After 24 hours of incubation with the vehicle and the treatments, the cell culture media was collected and frozen at $-20{ }^{\circ} \mathrm{C}$ until the measurement of the total nitrite concentration by the Griess Reaction (Cayman Chemical Company; Cat\#: 780001). Briefly, nitrite blanks, standards, and the sample media were incubated with Griess reagent 1 , followed by Griess reagent 2. After incubating for 10 minutes at RT, the absorbance was measured at $540 \mathrm{~nm}$. The nitrite concentration in the media samples was expressed in micromolar $(\mu M)(24)$.

\section{Western blotting and densitometry analysis}

After the incubation with the vehicle and the treatments, cell lysates containing $50 \mathrm{ug}$ of protein were separated using 4-15\% Tris-HCl PAGE precast gels (Bio-Rad, Hercules, CA) in Tris/glycine/SDS running buffer. The separated proteins were electrophoretic transferred onto polyvinylidene fluoride (PVDF) membranes in Tris/glycine/ methanol transfer buffer using transblot semi-dry apparatus (Bio-Rad, Hercules, CA, USA). Membranes were blocked in $5 \%$ non-fat milk with $0.1 \%$ Tween 20 in PBS for one hour at RT, as it was previously described $(19,24)$. After several washes with the PBS Tween $0.1 \%$ washing buffer, membranes were incubated overnight at $4{ }^{\circ} \mathrm{C}$ with the primary antibodies for (I) iNOS at 1:250 dilution (Abcam Cat\# ab15323, RRID:AB_301857 Cambridge, UK); (II) eNOS at 1:500 dilution (BD Biosciences Cat\# 610299, RRID:AB_397693 San Jose, CA, USA); (III) nNOS at 1:500 dilution (Abcam Cat\# ab76067, RRID:AB_2152469); (IV) the amino acid transporter SLC38A1/NAT2 at 1:800 


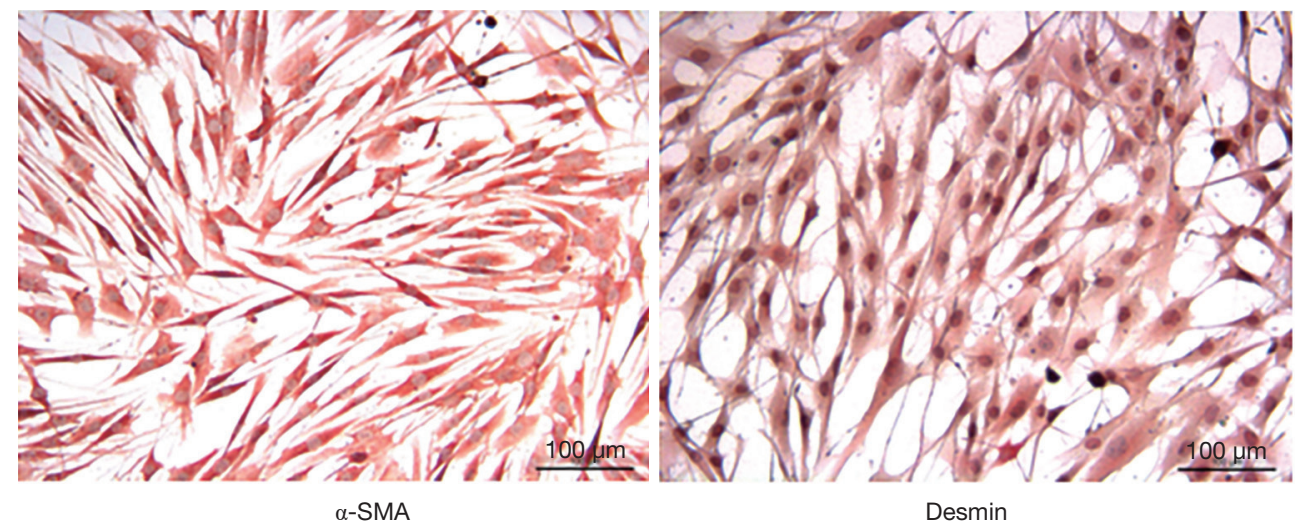

Figure 1 Characterization of human smooth muscle cell in culture. HCSMC ( $n=4)$ were subjected to immunohistochemistry for alpha smooth muscle actin and desmin using antibodies and AEC as chromogen. Magnification 200×, bar =100 $\mu$ m. HCSMC, human cavernosal smooth muscle cell. $\alpha$-SMA, alpha smooth muscle actin.

dilution (Abcam Cat\# ab134268, RRID:AB_945505). GAPDH at 1:5000 dilution was used as a loading control (Millipore Cat\# MAB374, RRID:AB_2107445, Billerica, MA, USA). After several washes with buffer, the membranes were incubated for 2 hrs at RT with 1:2,000 dilution of anti-mouse or anti-rabbit secondary antibody linked with HRP (Cell Signaling Technology, Cat\# 7076, RRID:AB_330924 and Cat\# 7074, RRID:AB_2099233, Danvers, MA, USA). The immunoreactive bands were visualized using a chemiluminescent detection system, WesternSure PREMIUM (Li-COR Biotechnology Cat\# 926-95000, Lincoln, NE, USA). The bands were scanned with C-DiGit Blot Scanner (Li-COR Biotechnology) and analyzed with the Image Studio Software, version $5.2(\mathrm{Li}-$ COR Biotechnology).

\section{Statistical analysis}

All data are presented as mean \pm S.E.M. Differences between groups were analyzed by one-way ANOVA followed by Dunnett's multiple comparisons test using GraphPad Prism version 8.0.0 (GraphPad Software, San Diego, CA). All comparisons were two-tailed, and $\mathrm{P}<0.05$ were considered statistically significant. Cells were seeded in 6-well plates at 0.3106 cells per well or four-well chambers at 40,000 cells per well using simple randomization. All in vitro experiments were repeated at least thrice from four different patients $(n=4)$, and the data from representative experiments are shown.

\section{Results}

In order to determine the purity of the HCSMC primary cell culture, immunohistochemistry was performed with two smooth muscle cell markers, alpha smooth muscle actin and desmin. Figure 1 shows a strong positive expression of both markers in which $100 \%$ of the cells in each well expressed both alpha smooth muscle actin and desmin indicating that the primary cell culture only contained smooth muscle cells (25). This corroboration of the positive staining for $\alpha$-smooth muscle actin and desmin was done in all the patients in order to maintain the integrity of the study.

To determine whether Revactin ${ }^{\circledR}$ was capable of stimulating NO production in the HCSMC, nitrite formation was measured in the medium after the cells were incubated with different concentrations of Revactin ${ }^{\circledR}$. Figure $2 A$ shows that the $50 \%$ Revactin ${ }^{\circledR}$ dose increased nitrite production by $30.5 \%(\mathrm{P}=0.0247)$; the $100 \%$ dose of Revactin ${ }^{\otimes}$ increased it by $74 \%(\mathrm{P}<0.0001)$; and the $200 \%$ dose of Revactin ${ }^{\circledR}$ increased it by $61 \%(\mathrm{P}=0.0003)$, when compared with the control. As expected, the PDE inhibitor IBMX did not stimulate nitrite formation.

To ascertain whether the increase in nitrite formation, a surrogate for $\mathrm{NO}$ production, was translated into the activation of the endogenous NO-cGMP pathway in the HCSMC, cGMP production was determined similarly with the $50 \%, 100 \%$, and $200 \%$ concentrations of Revactin ${ }^{\circledR}$. As seen in Figure 2B, after 24 hours of incubation and 


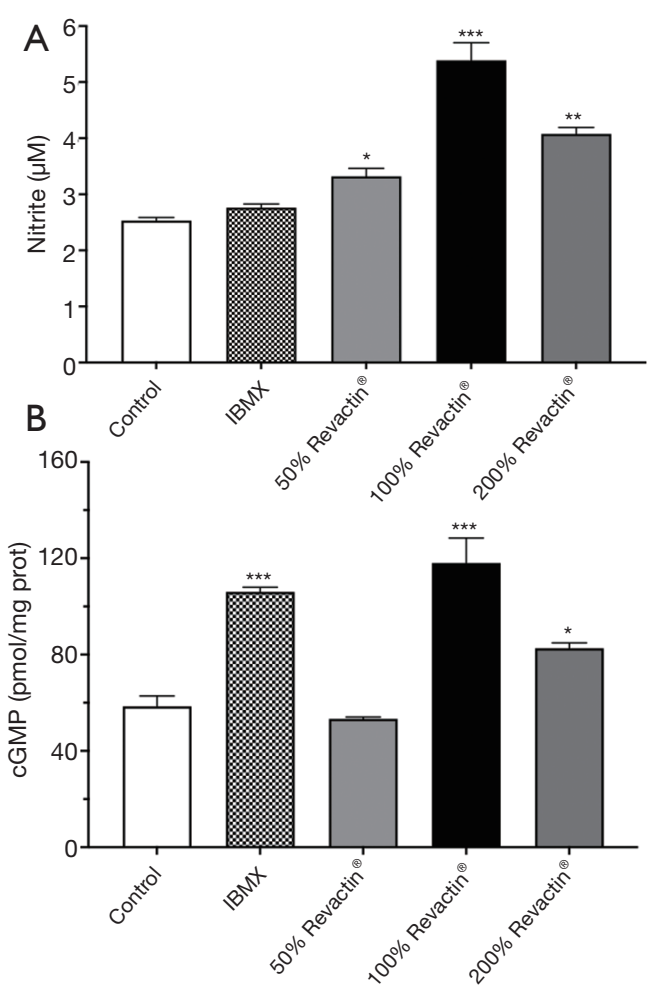

Figure 2 Effect of the incubation of different concentrations of Revactin ${ }^{\circledR}$ on nitrite formation and cGMP expression human cavernosal smooth muscle cell culture. HCSMC were incubated for 24 hours with or without $50 \%$ Revactin ${ }^{\circledR}(0.345 \mathrm{mg} / \mathrm{mL}), 100 \%$ $\operatorname{Revactin}^{\circledR}(0.69 \mathrm{mg} / \mathrm{mL})$, and $200 \% \operatorname{Revactin}^{\circledR}(1.38 \mathrm{mg} / \mathrm{mL})$. The cell culture media and the HCL supernatant extract from treated and control cells were collected and frozen at $-80{ }^{\circ} \mathrm{C}$. (A) Nitrite formation was determined by Griess reaction. (B) cGMP was determined by ELISA. IBMX (1 $\mathrm{mM})$ was employed as a positive control for cGMP expression. Results for nitrite formation are expressed as $\mu \mathrm{M}$ and for cGMP expression are expressed as $\mathrm{pmol} / \mathrm{mg}$ protein and represent the mean \pm S.E.M of four experiments done in duplicates. ${ }^{*} \mathrm{P}<0.05 ;{ }^{* *} \mathrm{P}<0.01$; ${ }^{* * *} \mathrm{P}<0.001$ vs. control. HCSMC, human cavernosal smooth muscle cell.

when compared to the control, there was no significant difference in cGMP $(\mathrm{P}=0.8873)$ production with the $50 \%$ concentration of Revactin ${ }^{\circledR}$. However, with the $100 \%$ Revactin $^{\circledR}$ concentration, there was a significant 2.0 -fold increase in the production of cGMP $(\mathrm{P}<0.0001)$, while with the $200 \%$ Revactin ${ }^{\circledR}$ dose, there was only a $41 \%$ increase in cGMP production $(\mathrm{P}=0.0266)$. When the CSMC were incubated with IBMX which was used as our positive control, there was a 1.8 -fold increase in cGMP production $(\mathrm{P}=0.0003)$.

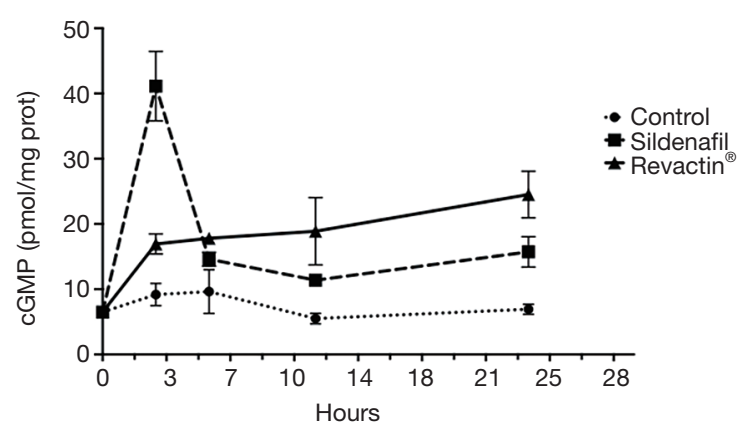

Figure 3 Time course of the effect of Revactin ${ }^{\circledR}$ on cGMP expression in comparison with sildenafil in human cavernosal smooth muscle cell culture. HCSM cells were incubated at different time points (from 0 to 24 hours) with or without Revactin $(0.69 \mathrm{mg} / \mathrm{mL})$, and sildenafil $(0.4 \mathrm{mM})$. Results are expressed as $\mathrm{pmol} / \mathrm{mg}$ protein and represent the mean \pm S.E.M of three experiments done in duplicate. HCSM, human cavernosal smooth muscle.

To corroborate that the time of the incubation with $100 \%$ Revactin ${ }^{\circledR}$ for 24 hours was the one that provided the highest cGMP production, a time course was performed in the HCSMC. Sildenafil was used as a positive control of cGMP expression. Figure 3 shows that while the cGMP expression was the highest for sildenafil at 3 hours of incubation, Revactin ${ }^{\circledR}$ has a steady increase throughout the time course, reaching the maximum concentration of cGMP at 24 hours.

To determine whether the increase in NO production observed with Revactin ${ }^{\circledR}$ could be due to changes in the expression of any of the three endogenous nitric oxide synthases within the HCSMC, western blots were performed on these HCSMC treated with the $100 \%$ dose of Revactin ${ }^{\circledR}$. Figure 4 shows that this dose of Revactin ${ }^{\circledR}$ significantly increased iNOS expression by 2.9 -fold $(\mathrm{P}=0.0102)$ with respect to the control. The expression of the other two NOS synthases, eNOS and nNOS, were not upregulated by Revactin ${ }^{\circledR}$.

To demonstrate unequivocally that the effect of Revactin ${ }^{\circledR}$ is via its activation of iNOS, we co-incubated the $100 \%$ dose of Revactin ${ }^{\circledR}$ with L-NIL, a specific inhibitor of iNOS activity. Figure $5 A$ shows that L-NIL decreased nitrite formation by $45 \%(\mathrm{P}=0.018)$ and Figure $5 B$ shows that it decreased cGMP production by $43 \%$, when compared to its control.

To demonstrate that the amino acid L-CIT, one of the components of Revactin, is capable of entering the HCSMC, the expression of the neutral amino acid 

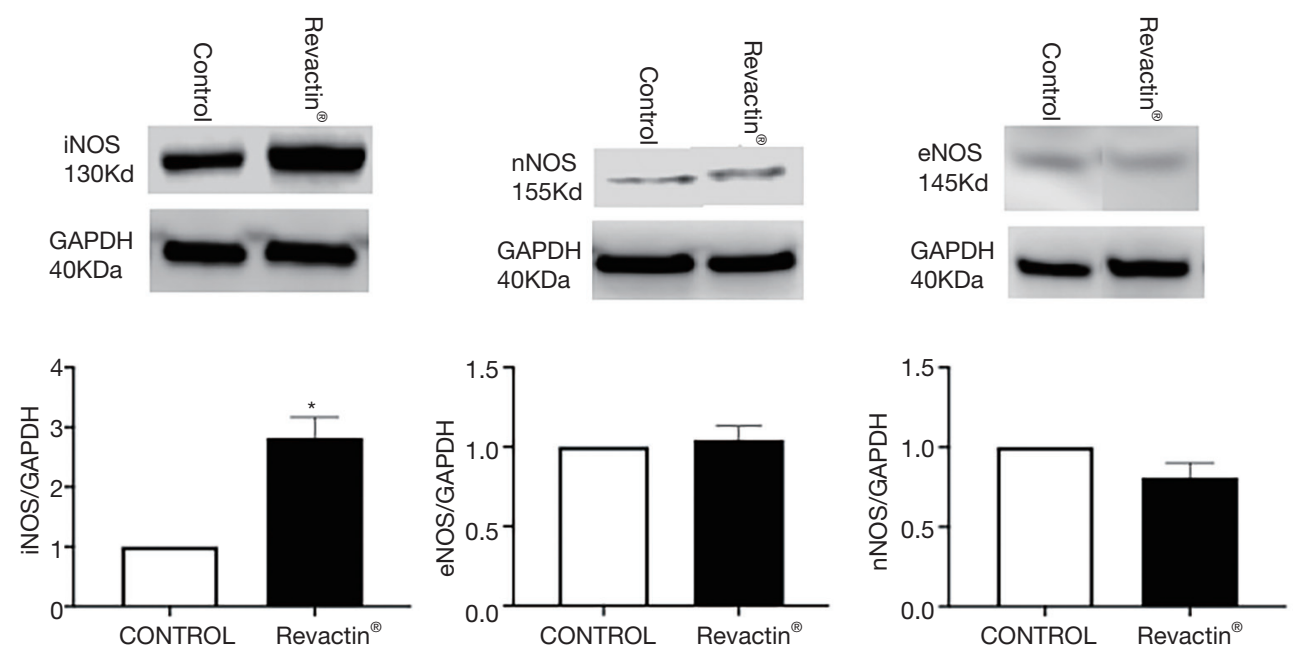

Figure 4 Effect of the incubation of Revactin ${ }^{\circledR}$ on the iNOS, nNOS and eNOS expressions in human cavernosal smooth muscle cell culture. iNOS, eNOS and nNOS protein expressions were determined by Western blot in HCSMC incubated for 48 hours with Revactin ${ }^{\circledR}$ $(0.69 \mathrm{mg} / \mathrm{mL})$. Results are expressed as a ratio with respect to control. Treated samples and control were normalized by GAPDH protein expression. ${ }^{*} \mathrm{P}<0.05$ respect to the control. iNOS, inducible nitric oxide synthase; HCSMC, human cavernosal smooth muscle cell.

transporter responsible for this action was evaluated by western blot. Figure 6 shows that amino acid transporter SLC38A1/NAT2 is expressed in our HCSM cell culture, and the addition of L-CIT or Revactin ${ }^{\circledR}$ did not modify its expression.

\section{Discussion}

This study demonstrates that Revactin ${ }^{\circledR}$ is capable of activating the normally dormant iNOS-NO-cGMP pathway within the HCSMC. In this in vitro study, exposure of the HCSMC to Revactin ${ }^{\circledR}$ for 24 hours resulted in an increase in the expression of iNOS and NO as well as an increase in the intracellular formation of cGMP. The NO-cGMP response to Revactin ${ }^{\circledR}$ is presumed to be solely iNOS dependent since incubation with the product increased the content of iNOS but not eNOS nor nNOS. In addition, L-NIL, a specific inhibitor of iNOS, was capable of completely blocking the formation of cGMP by Revactin ${ }^{\circledR}$. The increase in iNOS expression observed with Revactin ${ }^{\circledR}$ is probably due to either a modulation of the mRNA levels of iNOS, similar to what we have observed previously in the rat CSMC (19), or to post-trancriptional modifcations that would lead to an increase in the protein expression of iNOS.

The cGMP response to Revactin ${ }^{\circledR}$ appears to be dose dependent in that the maximum formation of cGMP in vitro occurred when the HCSMC were exposed to the corresponding recommended daily human dose which comprises $500 \mathrm{mg}$ each of ginger rhizome, muira puama and Paullinia cupana combined with approximately $1,600 \mathrm{mg}$ of L-citrulline (20,21). Even though $50 \%, 100 \%$ and $200 \%$ Revactin $^{\circledR}$ doses are all capable of inducing NO production by the HCSMC as is evidenced in our assay by the formation of nitrite (Figure 2A), a known footprint for NO, it was only the $100 \%$ and $200 \%$ doses that resulted in significant cGMP formation. Such an observation would indicate that a certain level of NO may be required to activate the soluble guanylyl cyclase (sGC) enzyme for the production of cGMP and several studies have shown that a high level of $\mathrm{NO}(250-1,600 \mathrm{nM})$ is actually required to produce half-maximal activity of this sGC enzyme (26). This could explain why the $100 \%$ and $200 \%$ but not the $50 \%$ Revactin $^{\circledR}$ doses were capable of promoting cGMP production. This dose dependency of the HCSMC to Revactin ${ }^{\circledR}$ parallels what was previously observed in a similar study in the rat where COMP-4, the four main constituents of Revactin $^{\circledR}$, was used to treat the cells singly or in combination (19).

It has been theorized that when the pre-determined aging related changes that impact corporal smooth muscle relaxation begin to occur in the CSMC most likely due to the onset of oxidative stress, the CSMC themselves begin to counteract this stress by initiating the production of NO intracellularly via this normally dormant iNOS 

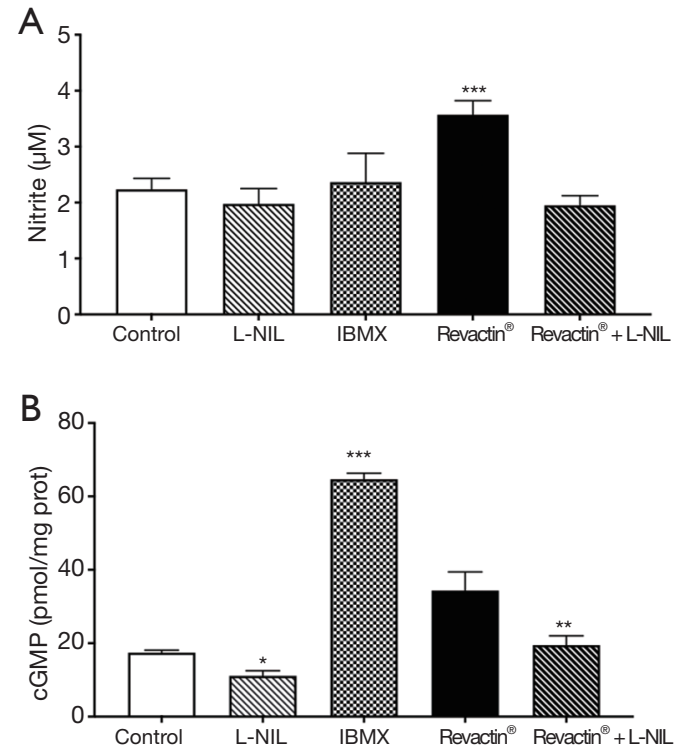

Figure 5 Incubation with L-NIL inhibits the stimulatory effect of Revactin $^{\circledR}$ on Nitrite formation and on cGMP expression in human cavernosal smooth muscle cell culture. Control, and Revactin ${ }^{\circledR}$ HCSMC cells were incubated for 24 hours with or without L-NIL (4 $\mu \mathrm{M})$. The cell culture media and HCL supernatant from treated and control cells were collected and frozen at $-80{ }^{\circ} \mathrm{C}$. (A) Nitrite formation was determined by Griess reaction. (B) cGMP expression was determined by ELISA. IBMX (1 $\mathrm{mM})$ was used as a positive control for cGMP expression. Results are expressed as $\mu \mathrm{M}$ for nitrite formation, and as $\mathrm{pmol} / \mathrm{mg}$ protein for cGMP expression and represent the mean \pm S.E.M of four experiments done in duplicates. ${ }^{*} \mathrm{P}<0.05 ;{ }^{* *} \mathrm{P}<0.01 ;{ }^{* *} \mathrm{P}<0.001$ vs. control. HCSMC, human cavernosal smooth muscle cell.

enzyme (17). The NO being produced by iNOS in such a scenario has a dual purpose: (I) to combat this oxidative stress by directly neutralizing within the mitochondria the newly formed reactive oxidation species (ROS) and (II) to form cGMP which begins a series of processes to repair the cellular changes that have occurred as a result of the damage done to the cellular architecture by the oxidative stress. In the aged rat, it was reported that such longterm daily treatment with the combination of these four constituents of Revactin ${ }^{\circledR}$ not only resulted in a marked improvement in the histology of the corpora (18) but it was determined that the response of the erectile tissue of these aged rats to pharmacological stimulation reverted to what is normally seen in much younger animals (18). In addition to the improvement in these histological and functional metrics of these treated aged animals, it was determined

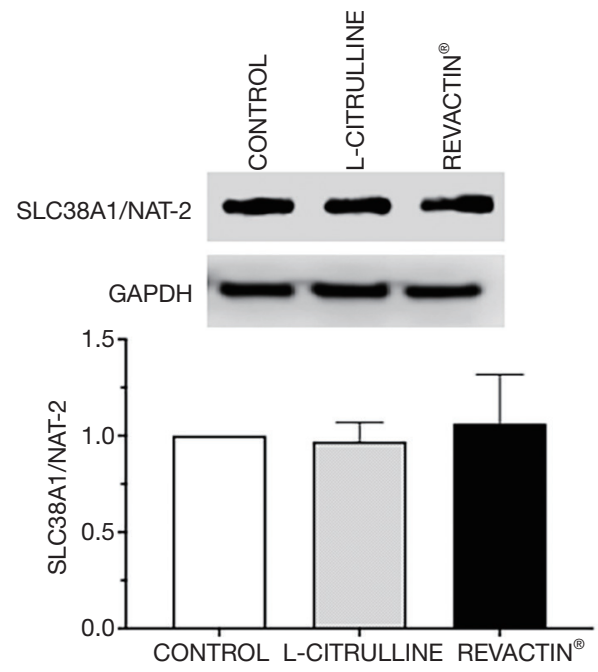

Figure 6 Effect of L-citrulline and Revactin ${ }^{\circledR}$ on the expression of the amino acid transporter SLC38A1/NAT2 expression in human cavernosal smooth muscle cells. SLC38A1/NAT2 protein expressions were determined by Western blot in HCSMC incubated for 48 hours with Revactin ${ }^{\circledR}(0.69 \mathrm{mg} / \mathrm{mL})$ and L-citrulline $(0.9 \mathrm{mg} / \mathrm{mL})$. Results are expressed as a ratio with respect to control. Treated samples and control were normalized by GAPDH protein expression. HCSMC, human cavernosal smooth muscle cell.

from measuring the GSH/GSSG ratio in the blood that the systemic oxidative stress of these treated aged animals was also markedly reduced (18) as evidenced by (I) the reduction in apoptotic activity and (II) no changes in the nitrotyrosine expression not only within the CSMC but also within the smooth muscle cells of the arterial media (27). This suggests that the combination of the products found in Revactin $^{\circledR}$ when ingested long-term may play a salutary role in combating systemic oxidative stress as well as stimulating those aged cells to begin repairing itself. This is somewhat similar to what has been shown to occur in a bone fracture model where the production of $\mathrm{NO}$, presumed to emanate from iNOS, accelerated fracture healing $(28,29)$ while the deletion of iNOS in this experimental model resulted in an impairment in the healing of these fractures (30). Besides its role in the bone and corporal tissue, a beneficial effect of iNOS has also been implicated in the process of repairing the intestinal mucosa after chronic injury $(31,32)$. In addition, it has been shown that delivery of iNOS to the skin using adenoviral vectors improved healing of this tissue in iNOS-/- mice (33), suggesting that iNOS may be therapeutically helpful if given in appropriately regulated 
amounts at specific sites (32).

Since our results show that Revactin ${ }^{\circledR}$ does not appear to modulate the expression of nNOS and eNOS within the HCSMC, this would suggest that the presumptive anti-oxidative, anti-fibrotic and anti-apoptotic effects of Revactin ${ }^{\circledR}$ is primarily the result of $\mathrm{NO}$ expression from iNOS (15). Furthermore, it also suggests that the improvement in erectile function previously reported in those men who took Revactin $(20,21)$ could most likely have been due to the production of $\mathrm{NO}$ via the upregulation of the endogenous iNOS-NO-cGMP pathway within the corporal smooth muscle itself and not due to any effect from eNOS nor nNOS.

Revactin ${ }^{\circledR}$ consists of four constituents, each demonstrating some individual involvement in either the NOS-NO-cGMP pathway or corporal smooth muscle relaxation or both (19). For example, specific forms of ginger at certain doses have been shown to stimulate iNOS and NO in RAW 264.7 cells (34), muira puama has been shown to stimulate the sGC enzyme, the enzyme that converts GTP to cGMP (35) while Paullinia cupana is known to increase cAMP rather than cGMP levels (35), as well as inhibit the synthesis of the PDE enzyme (19).

One of the limitations of this study is that although we have assumed that the production of NO from iNOS by Revactin $^{\circledR}$ could reduce oxidative stress within these HCSMC, such changes were not measured directly within the cell itself following incubation with the Revactin ${ }^{\circledR}$. In addition, it was not determined whether Revactin ${ }^{\circledR}$ had any effect on the expression of the PDE5 enzyme in these HCSMC although, Paullinia cupana, one of the constituents of the product has been shown in the rat CSMC to inhibit the expression of the PDE5 enzyme (19).

In summary, this in vitro study suggests that stimulation of the iNOS-NO-cGMP pathway within the HCSMC by Revactin ${ }^{\circledR}$ may play a role in combating the aging related deterioration of these cells resulting from the oxidative stress that is part and parcel of the normal aging process. It is obvious that appropriately designed human clinical trials will be necessary to determine this.

\section{Acknowledgments}

Funding: This study was funded in part by a grant from the Peter A Morton Foundation (JR). Certain aspects of the study were also supported in part by the NIH-National Institute on Minority Health and Health Disparities (NIH/ NIMHD) 5U54MD007598-06 (MGF).

\section{Footnote}

Reporting Checklist: The authors have completed the MDAR checklist. Available at https://dx.doi.org/10.21037/tau-21-11

Data Sharing Statement: Available at https://dx.doi. org/10.21037/tau-21-11

Peer Review File: Available at https://dx.doi.org/10.21037/ tau-21-11

Conflicts of Interest: All authors have completed the ICMJE uniform disclosure form (available at https://dx.doi. org/10.21037/tau-21-11). Dr. MGF reports a grant from NIH-National Institute on Minority Health and Health Disparities, during the conduct of the study. Dr. JR reports a grant from the Peter Morton Foundation and a stockholder in KLRM, LLC. KLRM, LLC is the assignee for the patent of COMB-4/COMP-4. MD Concepts pays KLRM, LLC a royalty on sales of Revactin ${ }^{\circledR}$. The authors have no other conflicts of interest to declare.

Ethical Statement: The authors are accountable for all aspects of the work in ensuring that questions related to the accuracy or integrity of any part of the work are appropriately investigated and resolved. The study was conducted in accordance with the Declaration of Helsinki (as revised in 2013). This study was approved as exempt by the UCLA IRB \#19-001074 and approved by the CDU IBC \#18-07-0034-01-03, and individual consent for this study was waived.

Open Access Statement: This is an Open Access article distributed in accordance with the Creative Commons Attribution-NonCommercial-NoDerivs 4.0 International License (CC BY-NC-ND 4.0), which permits the noncommercial replication and distribution of the article with the strict proviso that no changes or edits are made and the original work is properly cited (including links to both the formal publication through the relevant DOI and the license). See: https://creativecommons.org/licenses/by-nc-nd/4.0/.

\section{References}

1. Feldman HA, Goldstein I, Hatzichristou DG. Impotence and its medical and psychosocial correlates: Results of the Massachusetts Male Aging Study. J Urol 1994;151:54-61.

2. Rajfer J, Rosciszewski A, Mehringer M. Prevalence 
of corporeal venous leakage in impotent men. J Urol 1988;140:69-71.

3. Jevtich MJ, Khawand NY, Vidic B. Clinical significance of ultrastructural findings in the corpora cavernosa of normal and impotent men. J Urol 1990;143:289-93.

4. Sattar AA, Merckx LA, Wespes E. Penile electromyography and its smooth muscle content: interpretation of 25 impotent patients. J Urol 1996;155:909-12.

5. Nehra A, Goldstein I, Pabby A, et al. Mechanisms of venous leakage: a prospective clinicopathological correlation of corporeal function and structure. J Urol 1996;156:1320-9.

6. Yafi FA, Jenkins L, Albersen M, et al. Erectile dysfunction. Nat Rev Dis Primers 2016;2:16003.

7. Padma-Nathan H, Steers WD, Wicker PA. Efficacy and safety of oral sildenafil in the treatment of erectile dysfunction: a double-blind, placebo-controlled study of 329 patients. Sildenafil Study Group. Int J Clin Pract 1998;52:375-9.

8. Porst H, Rosen R, Padma-Nathan H, et al. The efficacy and tolerability of vardenafil, a new, oral, selective phosphodiesterase type 5 inhibitor, in patients with erectile dysfunction: the first at-home clinical trial. Int J Impot Res 2001;13:192-9.

9. Eardley I. Vardenafil: a new oral treatment for erectile dysfunction. Int J Clin Pract 2004;58:801-6.

10. El-Galley R, Rutland H, Talic R, et al. Long-term efficacy of sildenafil and tachyphylaxis effect. J Urol 2001;166:927-31.

11. Musicki B, Champion HC, Becker RE, et al. In vivo analysis of chronic phosphodiesterase- 5 inhibition with sildenafil in penile erectile tissues: no tachyphylaxis effect. J.Urol 2005;174:1493-6.

12. Vernet D, Magee T, Qian A, et al. Phosphodiesterase type 5 is not upregulated by tadalafil in cultures of human penile cells. J Sex Med 2006;3:84-94.

13. Ferrini M, Magee TR, Vernet D, et al. Aging-related expression of inducible nitric oxide synthase and markers of tissue damage in the rat penis. Biol Reprod 2001;64:974-82.

14. Pollack M, Leeuwenburgh C. Apoptosis and aging: role of the mitochondria. J Gerontol A Biol Sci Med Sci 2001;56:B475-82.

15. Ferrini MG, Vernet D, Magee TR, et al. Antifibrotic role of inducible nitric oxide synthase. Nitric Oxide 2002;6:283-94.

16. Ferrini MG, Rivera S, Moon J, et al. The genetic inactivation of inducible nitric oxide synthase (iNOS) intensifies fibrosis and oxidative stress in the penile corpora cavernosa in type 1 diabetes. J Sex Med 2010;7:3033-44.

17. Ferrini MG, Gonzalez-Cadavid NF, Rajfer J. Aging related erectile dysfunction-potential mechanism to halt or delay its onset. Transl Androl Urol 2017;6:20-7.

18. Ferrini MG, Hlaing SM, Chan A, et al. Treatment with a combination of ginger, L-citrulline, muira puama and Paullinia cupana can reverse the progression of corporal smooth muscle loss, fibrosis and veno-occlusive dysfunction in the aging rat. Andrology (Los Angel) 2015;4:e132.

19. Ferrini MG, Garcia E, Abraham A, et al. Effect of ginger, Paullinia cupana, muira puama and 1- citrulline, singly or in combination, on modulation of the inducible nitric oxide- NO-cGMP pathway in rat penile smooth muscle cells. Nitric Oxide 2018;76:81-6.

20. Nguyen S, Rajfer J, Shaheen M. Safety and efficacy of daily Revactin ${ }^{\circledR}$ in men with erectile dysfunction: a 3-month pilot study. Transl Androl Urol 2018;7:266-73.

21. Nguyen S, Shaheen M, Pak Y, Rajfer J. Early improvement in SHIM scores with Revactin®. Int J Impot Res 2020;32:255-6.

22. Elliott KJ, Eguchi S. In Vitro Assays to Determine Smooth Muscle Cell Hypertrophy, Protein Content, and Fibrosis. Methods Mol Biol 2017;1614:147-53.

23. Braga M, Simmons Z, Norris KC, et al. Vitamin D induces myogenic differentiation in skeletal muscle derived stem cells. Endocr Connect 2017;6:139-50.

24. Ferrini MG, Abraham A, Nguyen S, et al. Exogenous L-Arginine does not stimulate production of $\mathrm{NO}$ or cGMP within the rat corporal smooth muscle cells in culture. Nitric Oxide 2019;89:64-70.

25. Rangdaeng S, Truong LD. Comparative Immunohistochemical Staining for Desmin and MuscleSpecific Actin: A Study of 576 Cases. Am J Clin Pathol 1991:96:32-45.

26. Chen K, Pittman RN, Popel AS. Nitric oxide in the vasculature: where does it come from and where does it go? A quantitative perspective. Antioxid Redox Signal 2008;10:1185-98.

27. Nguyen S, Castellanos KA, Abraham A, et al. Reduction of oxidative stress markers in the corpora cavernosa and media of penile dorsal artery in middle-aged rats treated with COMP-4. Int J Impot Res 2021;33:67-74.

28. Rajfer RA, Kilic A, Neviaser AS, et al. Enhancement of fracture healing in the rat, modulated by compounds that stimulate inducible nitric oxide synthase: Acceleration of fracture healing via inducible nitric oxide synthase. Bone 
Joint Res 2017;6:90-7.

29. Diwan AD, Wang MX, Jang D, et al. Nitric oxide modulates fracture healing. J Bone Miner Res 2000;15:342-51.

30. Baldik Y, Diwan AD, Appleyard RC, et al. Deletion of iNOS gene impairs mouse fracture healing. Bone 2005;37:32-6.

31. McCafferty DM, Mudgett JS, Swain MG, et al. Inducible nitric oxide synthase plays a critical role in resolving intestinal inflammation. Gastroenterology 1997;112:1022-7.

32. Kubes P Inducible nitric oxide synthase: a little bit of good in all of us. Gut 2000;47:6-9.

Cite this article as: Ferrini MG, Abraham A, Graciano L, Nguyen S, Mills JN, Rajfer J. Activation of the iNOS/NO/ cGMP pathway by Revactin ${ }^{\circledR}$ in human corporal smooth muscle cells. Transl Androl Urol 2021;10(7):2889-2898. doi: 10.21037/tau21-11
33. Yamasaki K, Edington HD, McClosky C, et al. Reversal of impaired wound repair in iNOS-deficient mice by topical adenoviral-mediated iNOS gene transfer. J Clin Invest 1998;101:967-71.

34. Imanishi N, Mantani N, Sakai S, et al. Inducible activity of ginger rhizome (Zingiber officinale Rosc.) on the mRNA expression of macrophage-inducible nitric oxide (NO) synthase and NO production in a macrophage cell line, RAW264.7 cells. Am J Chin Med 2004;32:727-35.

35. Antunes E, Gordo WM, de Oliveira JF, et al. The relaxation of isolated rabbit corpus cavernosum by the herbal medicine Catuama and its constituents. Phytother Res 2001;15:416-21. 